\begin{tabular}{|c|c|c|c|c|}
\hline Substance & $\begin{array}{l}R F \text { va } \\
\text { butanol- } \\
\text { acetic } \\
\text { acid- } \\
\text { water }\end{array}$ & $\begin{array}{l}\text { ue in } \\
\text { phenol- } \\
\text { water }\end{array}$ & $\begin{array}{l}\text { Intensity } \\
\text { of spots }\end{array}$ & $\begin{array}{c}\text { Approx. conc. } \\
\text { in yolk } \\
\text { (mgm. } \\
\text { per cent) }\end{array}$ \\
\hline $\begin{array}{l}\text { Peptide } \\
\text { containing } \\
\text { lysine } \\
\text { Lysine* } \\
\text { Aspartic acid } \\
\text { Unknown* } \\
\text { Arginine } \\
\text { Glycine } \\
\text { Glutamic acid } \\
\text { Threonine } \\
\text { Citrulline } \\
\text { Alanine } \\
\text { Unknown } \\
\text { Tyrosine } \\
\text { Valine } \\
\text { Leucine }\end{array}$ & $\begin{array}{l}0.09 \\
0.07 \\
0.21 \\
0.23 \\
0.13 \\
0.22 \\
0.30 \\
0.28 \\
0.20 \\
0.34 \\
0.22 \\
0.46 \\
0.52 \\
0.68\end{array}$ & $\begin{array}{l}0.21 \\
0.35 \\
0.40 \\
0.34 \\
0.45 \\
0.45 \\
0.45 \\
0.54 \\
0.64 \\
0.58 \\
0.81 \\
0.64 \\
0.79 \\
0.85\end{array}$ & $\begin{array}{c}+ \\
++ \\
++ \\
+ \\
+++ \\
+ \\
++ \\
++ \\
+ \\
++ \\
+ \\
+ \\
++ \\
+++\end{array}$ & 150 \\
\hline
\end{tabular}

* Obtained after hydrolysis.

The various amino-acids are all among those reported from yolk-protein ${ }^{1}$. In the white, there are no demonstrable free amino-acids; but in the yolk freed from the blastoderm the concentration is excep. tionally high. Consequently, mobilization of aminoacids occurs in the yolk apparently independently of the embryo. For this reason it may be assumed that pre-formed proteolytic enzymes are active in the yolk.

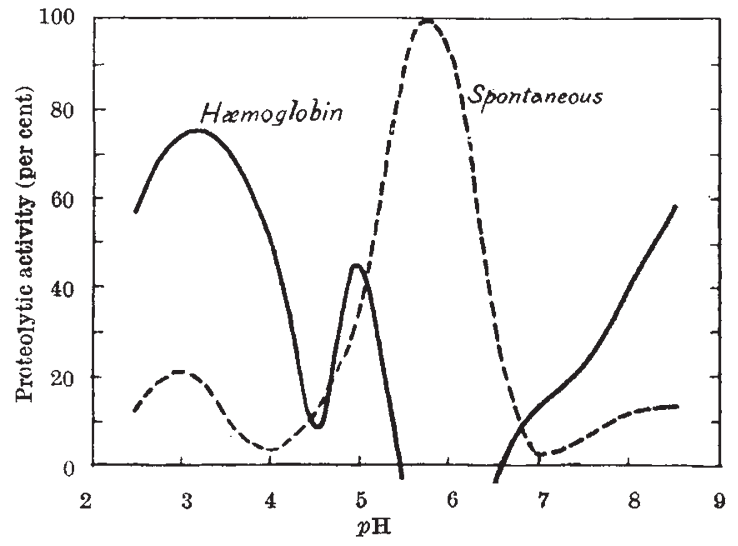

$p$ H-Activity of yolk proteinases in the hen's egg

For determination of this expected proteolytic activity, extracts of yolk freed from blastoderm were made with glycerol-water ( 30 per cent) and used immediately. As substrate undenatured hæmoglobin was used in 1 per cent solution. Merthiolate was added. Samples mixed with buffer solution (MacIlvaine's standard buffer) were incubated at $39^{\circ} \mathrm{C}$. for $2 \mathrm{hr}$. The proteolysis was stopped by adding trichloracetic acid ( 5 per cent). Samples were examined in the spectrophotometer at $2750 \mathrm{~A}$. for liberated cyclic amino-acids. Rectilineal curves were obtained for at least five hours. From the accompanying graph it is apparent that there are at least three proteinases in the yolk, acting at different $p H$ 's. The spontaneous activity around $p H \quad 6$ is very high, and addition of hæmoglobin has apparently an inhibiting effect thereupon.

The work is being continued and further results will be published elsewhere.

Zoophysiological Institution

Hadar FmanUelsson

University, Lund.

June 15.

${ }^{1}$ Romanoff, A. L., and Romanoff, A. J., "The Avian Egg", 334 (1949).

\section{Chromatographic Analysis of Amino- acids of Molasses and other Beet-sugar Industry By-products}

WE have applied chromatographic analysis to the detection of the amino-acids present in beet molasses and other by-products of the sugar-beet industry.

We used the descending paper-chromatography technique described by Consden, Gordon and Martin ${ }^{1}$; Whatman No. 1 paper, and the phenol, lutidine + collidine system were used. A $0 \cdot 1$ per cent solution of ninhydrin in butanol was used for detecting the spots.

Most of the chromatograms were obtained without any purification of exhausted molasses; in every run we used $5 \mathrm{mgm}$. of substance dissolved in distilled water $(1: 10 \mathrm{w} / \mathrm{v})$. The chromatograms show nine spots well separated; after several trials we are able to attribute the spots to the following amino-acids: aspartic, glutamic, $\gamma$-aminobutyric, serine, glycine, alanine, valine, leucine, tyrosine. A good deal of pyrrolidone carboxylic acid is also present. This does not give a spot with ninhydrin; but the chromatograms made after treatment by acid hydrolysis of the molasses show a broader and more intense spot of glutamic acid. No traces of basic or sulphurated amino-acids were found. A detailed account of this work will be published. elsewhere.

Applying a desalting procedure to the molasses solutions we obtained clearer chromatograms, with sharper spots. For this purpose we used a desalting apparatus analogous to that described by Consden, Gordon and Martin ${ }^{2}$. The chromatograms obtained in this way give, besides the nine spots already identified, another spot, much weaker than the others, due to threonine. The accompanying photograph is of a chromatogram obtained with desalted molasses.

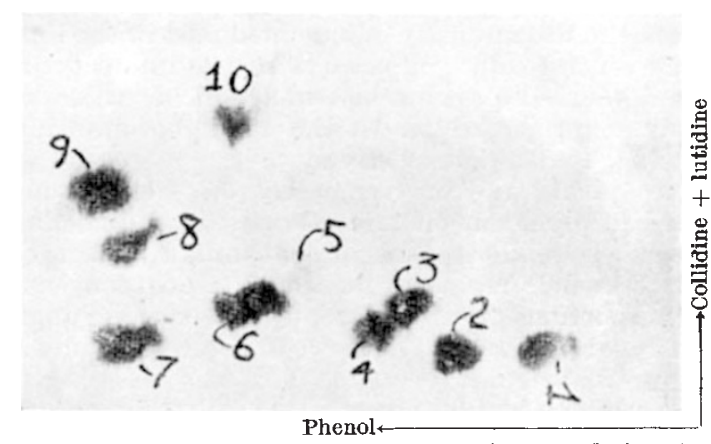

(1) Aspartic acid, (2) glutamic acid, (3) serine, (4) glycine, (5) (9) leucine, (10) tyrosine

Regarding the quantity of amino-acids, in so far as the spots show, we can say that the most intense spot is that due to alanine; the $\gamma$-aminobutyric, glutamic and leucine spots follow in order of intensity. The spots due to aspartic acid, glycine, serine, valine and tyrosine are less intense.

We have found the same amino-acids in a sample of concentrated baryta-process waste liquors, and in different samples of first-run molasses.

\section{Eugenio MarLani}

GIORgIo Torraca

Istituto di Chimica Applicata ed Industriale,

Facoltà Ingegneria, Università di Roma. June 30.

${ }^{1}$ Biochem. J., 38, 224 (1944)

2 Bischem. J., 41, 580 (1947). 